\title{
Personal Branding Selebritas dan Bisnis Online Shop
}

\author{
${ }^{1}$ Rostika Yuliani, ${ }^{2}$ Susanne Dida \\ ${ }^{1,2}$ Fakultas Ilmu Komunikasi, Universitas Padjadjaran, Bandung \\ Email: ${ }^{1}$ rostika.yuliani@gmail.com, ${ }^{2}$ sussannedida@gmail.com
}

\begin{abstract}
Abstrak.Personal branding secara sederhana dapat diartikan sebagai pembangunan merek atas diri seseorang. Zaskia Adya Mecca merupakan seorang artis dan presenter yang sukses merintis kariernya hingga saat ini, dan pada awal tahun 2012 ini Zaskia Adya Mecca ini merilis bisnis busana Muslimah yang dijual baik secara online maupun secara offline. Tujuan bisnis Zaskia Adya Mecca ini membuat bisnis adalah agar masyarakat bisa tertarik untuk membeli produk-produk yang dia miliki dengan memanfaatkan teknologi yang ada melalui website, social media seperti instagram. Motif dari Zaskia Adya Mecca ini melakukan personal branding melalui media sosial di instagram dan website adalah sebagai sarana untuk mempromosikan produk-produk yang dimiliki oleh Zaskia Adya Mecca kepada para penggemar dan konsumennya untuk tertarik membeli produkproduk yang dijualnya baik secara online maupun offline. Adapun keunggulan produk-produk yang dimiliki oleh Zaskia Adya Mecca adalah model-modelnya lebih menarik, simple,elegan dan tidak pasaran dan dari segi harga masih terjangkau oleh beberapa kalangan, khususnya kalangan menengah keatas.
\end{abstract}

Kata kunci: personal branding, online shop

\begin{abstract}
Personal branding can simply be interpreted as a brand development on a person. Zaskia Adya Mecca is a successful actor and presenter still build her career to this day, and at the beginning of 2012 Zaskia Adya Mecca released Muslim clothing business that is sold both online and offline. Her purposes to running the business is to make society interested to buy her products by utilizing the existing technology through the website, social media such as instagram. The motive of Zaskia Adya Mecca doing personal branding by using social media in instagram and website is to promote products owned by Zaskia Adya Mecca to the fans and consumers so they will interested to buy products that are sold both online and offline. The superiority of the products owned by Zaskia Adya Mecca are attractive models, simple, elegant, limited models and the price is still affordable by some circles, especially the upper middle class.
\end{abstract}

Keywords : personal branding, online shop 


\section{PENDAHULUAN}

Di era persaingan bisnis yang semakin ketat dan semakin majunya teknologi dalam mempermudah bisnis dan penjualan produk, banyak pebisnis yang bermunculan, tidak hanya pengusaha saja yang semakin banyak yang melakukan bisnis, tetapi saat ini banyak sekali kalangan artis yang saat ini selain menjadi public figure di dunia entertainment juga sedang merambah atau terjun ke dunia bisnis.

Adapun para artis ini saling bersaing untuk terjun ke dunia bisnis baik secara online ataupun offline dalam hal ini membuka toko secara langsung di beberapa kota dan bisnis-bisnis yang dilakukan para artis ini bermacam-macam terdiri atas bisnis makanan dan minuman seperti kue, roti, snack kemasan, ayam geprek, minuman kesehatan, restoran, bisnis fashion untuk wanita muslimah, fitness center, bisnis make up, produk kecantikan, parfum, property, kostkostan, karaoke, salon, event organizer, ternak dan perkebunan, hotel \& resort, perhiasan, accessories, dan masih banyak lagi bisnis yang lainnya.

Seperti yang dinyatakan Fuady (2002), kemajuan teknologi komunikasi meniadakan sekat dan jarak yang membatasi individu satu dan lainnya. Keunggulan itu digunakan oleh para artis. Tren artis untuk melakukan bisnis memiliki berbagai macam alasan di antaranya karena sebagai ladang investasi dari kerja keras mereka selama berkecimpung sebagai public figure dan apabila artis tersebut sudah tidak eksis atau sudah pensiun dari dunia entertainment, selain itu juga kebanyakan dari artis ini memanfaatkan momen ketenarannya untuk melakukan bisnis ingin melakukan hubungan komunikasi yang baik di antara artis dengan para followers yang ada di akun instagram sehingga para followers dapat memberikan saran dan masukan untuk kemajuan bisnis dari artis tersebut.
Untuk membentuk suatu personal branding menjadi cara untuk meningkatkan nilai jual seseorang. Personal branding adalah proses membawa skill, kepribadian, dan karakter unik seseorang untuk kemudian dapat membungkusnya menjadi sebuah identitas yang memiliki kekuatan lebih dibandingkan dengan yang lain. Personal branding secara tidak langsung telah dibangun oleh seseorang individu dari sebuah perkerjaan atau profesi yang ia lakukan. Personal branding merupakan proses yang akan membawa ketrampilan, kepribadian dan karakteristik unik seseorang dan kemudian membungkusnya menjadi identitas yang memiliki kekuatan lebih dibanding pesaing. Adapun kegiatan personal branding melalui internet sudah berhasil melahirkan banyak idola atau endorser di Indonesia.

Sebagai media sosial dengan jumlah pengguna yang tinggi, Instagram sering dimanfaatkan perusahaan dalam memasarkan produknya serta melakukan branding. Melalui media sosial ini, perusahaan mendapat kesempatan untuk berinteraksi secara langsung dengan customer. Selain aktivitas perusahaan, saat ini banyak pihak secara individu mulai melakukan kegiatan personal branding melalui instagram.

Salah satu artis yang menggunakan Instagram sebagai media untuk memromosikan online shop adalah Zaskia Adya Mecca. Zaskia Adya Mecca ini merupakan seorang artis sekaligus presenter. Selain menjadi seorang artis dan presenter, Zaskia ini tengah menekuni bisnis online shop di bidang fashion busana Muslim yang dirilis sejak awal 2012 silam itu mengalami perkembangan yang cukup pesat yang di mana Zaskia Adya Mecca memiliki alasan untuk membuka bisnis busana Muslim ini adalah ingin menciptakan brand untuk gayanya sendiri, yaitu gaya casual yang praktis, tetapi tetap elegan dan modis, selain itu 
juga karena beliau ingin menyampaikan kepada masyarakat khususnya kaum wanita Muslimah untuk menutup aurat dengan menggunakan baju Muslim dan hijab, keinginan dari para fans dari Zaskia Adya Mecca untuk mengetahui tentang cara dan gaya berpakaiannya dalam berbagai kesempatan dan yang terakhir adalah ingin mengajak bekerjasama dalam berbisnis dengan adik dan kakaknya Zaskia, yaitu Haikal Kamil dan Tasya Nur Medina.

Meskipun Zaskia Adya Mecca pada saat ini sedang menjalankan bisnis busana muslim tetapi hal ini tidak berpengaruh terhadap eksistensi Zaskia Adya Mecca di dunia entertainment walaupun Zaskia ini sempat bingung untuk mengatur waktu antara kegiatannya sebagai artis sinetron dan presenter dengan profesinya yang terbaru sebagai pengusaha busana Muslim, tetapi keputusan terakhirnya adalah untuk memilih menjadi seorang pengusaha dan Zaskia menganggap bahwa menjadi pengusaha itu merupakan passion-nya dari awal sebelum menjadi artis sinetron.

Adapun modal yang dikeluarkan untuk membuka bisnis ini adalah 100 juta dan alasan di balik pembuatan website dan akun instagram online shopnya adalah semakin canggihnya teknologi telah mampu membawa para ibu menjadi entrepreneur muda.

Dalam melakukan bisnis busana Muslimnya, Zaskia memanfaatkan teknologi untuk memasarkan produknya dengan cara menggunakan online shop, di antaranya adalah website meccanism. co dan memiliki akun instagramnya, yaitu@meccanismbyzaskiamecca. Hal ini dapat dilihat pada Gambar 1.

Adapun konten dari online shop milik Zaskia ini yang di-posting baik melalui website ataupun melalui akun instagramnya ini berisi tentang produkproduk yang dijual oleh Zaskia Adya Mecca yang berfokus secara khusus mengenai busana muslimah. Zaskia Adya Mecca memanfaatkan kekuatan media sosial Instagram untuk menyampaikan pesan kepada para pengikutnya. Aktivitas yang ia lakukan di media sosial seputar foto atau video tentang kegiatan sehari-seharinya yang bisa menginspirasi pengikutnya, seperti pola hidup sehat, endorse produk-produk lain selain dari produk yang dijualnya, tutorial penggunaan hijab dan kegiatan berolahraga. Ia juga kerap mengunggah foto bersama keluarganya untuk selalu kompak dalam menjalankan aktivitasnya sehari-hari.

Selain menjual barang-barangnya dalam produk online, ada juga barangbarang yang dijual secara offline, sehingga

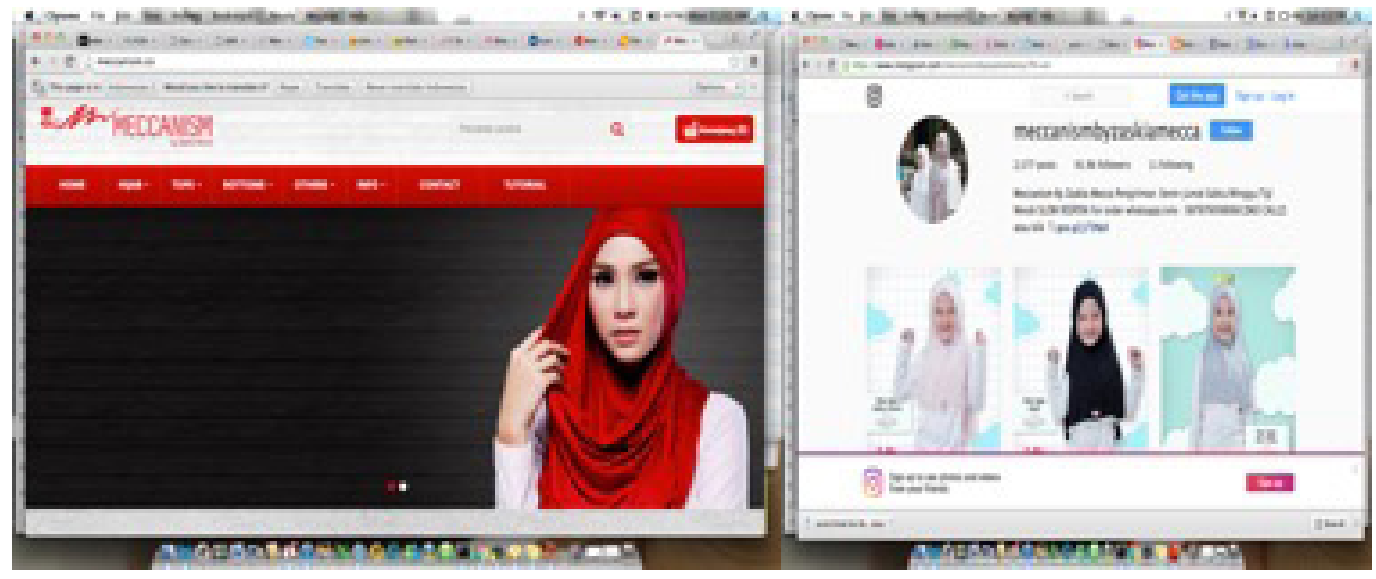

GAMBAR 1. Website \& Instagram Online Shop Milik Zaskia Adya Mecca Sumber: website online shop meccanism.co dan akun instagram online shop@ meccanismbyzaskiamecca 
masyarakat bisa melihat secara langsung produk-produk yang dijual oleh Zaskia Adya Mecca.

Adapun produk-produk yang dijual oleh Zaskia Adya Mecca ini terdiri dari kerudung instan, jumpsuit (perpaduan antara rompi dengan celana), bandana, celana panjang, kaos manset panjang, kaos manset tanpa lengan, baju syar'i, cardigan, ciput, kerudung segiempat, baju gamis, pashmina, kaos kaki, kerudung khusus anak-anak, dan outer.

Target sasaran yang diincar oleh Zaskia Adya Mecca dalam menjual produk busana Muslimnya adalah anakanak berusia 6-8 tahun, kalangan remaja, ibu-ibu muda dan kalangan wanita dewasa. Harga produk yang dijual di dalam bisnisnya ini terdiri atas 25000 hingga 329.900 .

Perkembangan bisnis yang semakin besartentutidak diawalidengan perjalanan yang mudah dan instan. Butuh kemauan serta kerja keras untuk mendapatkan hasil yang maksimal. Tidak ada tantangan yang terlalu membebani keduanya ketika baru mendirikan butik. Ia mengaku tantangan diawal justru datang dari pihak internal yaitu perbedaan pendapat antara Zaskia dan kakaknya.

Berdasarkan latar belakang tersebut, tim peneliti tertarik untuk menganalisis bagaimana personal branding yang dilakukan Zaskia Adya Mecca pada awal kariernya sebagai artis dan presenter berdasarkan online personal branding dan kepribadiannya sebagai artis sekaligus pengusaha. Melalui penelitian ini dapat dilihat bahwa kegiatan public relations tidak hanya dapat diaplikasikan oleh perusahaan atau organisasi, namun dapat pula dijadikan sebagai alat bagi individu dalam melakukan branding atas dirinya.

Adapun pertanyaan penelitian yang digunakan dalam penelitian ini adalah

(1) Bagaimana personal branding yang dilakukan oleh Zaskia Adya Mecca Dalam Melakukan bisnis fashion online shop?

(2) Bagaimana Kepribadian Zaskia Adya Mecca dalam membentuk personal branding?

\section{Konsep dan Teori Personal Branding and Online Shop}

Ganiem dalam Wasesa (2013: 282) Personal Branding adalah bagaimana kita memasarkan dan merepresentasikan diri kita pada orang lain. Orang yang melakukan personal branding dengan baik cenderung mendapat popularitas sesuai atau mendekati harapannya. Menurut Mc Nally \& Speak (2012) yang dikutip dari Jurnal yang berjudul "Analisis Personal Branding Fashion Blogger Diana Rikasari" yang ditulis Amanda Vivi Imawati, Ayu Wahyuni Solihah, Mohammad Shihab. Ada beberapa karakteristik yang harus diperhatikan dalam merancang personal brand yang kuat yakni sebagai berikut.

(a) Khas, yakni personal brand yang tidak hanya berbeda, tetapi merupakan cerminan dari ide-ide dan nilai-nilai dalam diri Anda yang membentuk kekhasan Anda. Adapun di dalam penelitian ini yang menjadi khas adalah baju muslim.

(b) Relevan, yakni apa yang diwakili personal brand tersebut relevan dengan apa yang dianggap penting atau dibutuhkan orang lain.

(c) Konsisten, yakni menjalankan personal brand yang dirancang secara terus-menerus, sehingga audiens dapat mengidentifikasi personal brand dengan mudah dan jelas. Adapun di dalam penelitian ini konsisten berkaitan dengan kehidupan masyarakat Indonesia ini mayoritasnya adalah Muslim.

Menurut Ryann Frischmann (2014), online personal brand terrepresentasikan diri seseorang ketika berinteraksi 
dengan orang lain di dunia maya. Online personal brand yang seseorang miliki harus dapat menampilkan suatu karakter yang diinginkan serta membuat audiens ingin berinteraksi secara online dengan orang tersebut. Adapun Model tersebut ditunjukan dengan Gambar 2.

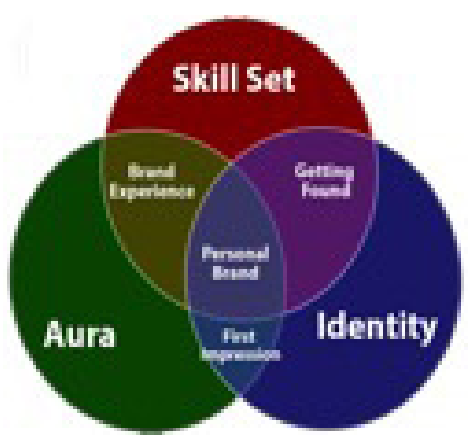

GAMBAR 2. Model Online Personal Branding Frischmann Sumber: Frischmann (2014)

Berdasarkan Gambar 2, Model Online Personal Branding menurut Frischmann (2014) terdapat tiga elemen utama yakni skill set, aura dan identity dengan penjelasan sebagai berikut.

(1). Skill Set

Elemen ini merepresentasikan nilai fungsional dan rasional dan didefinisikan sebagai kombinasi antara keahlian dan keterampilan yang dimiliki dari bidang pendidikan, pekerjaan, maupun berbagai pengalaman. Hal ini dapat dilihat dari keahlian \& kemampuan Zaskia Adya Mecca dalam melakukan bisnis online shop yang memberikan dampak positif kepada masyarakat.

(2). Aura

Elemen ini merepresentasikan nilai emosional yang memengaruhi persepsi publik. Aura meliputi kepribadian, penampilan, gaya, dan kharisma yang ditampilkan melalui media sosial. Aura ini dapat dilihat dari cara berpenampilan dalam menggunakan busana Muslim dan cara berbicara ketika memromosikan produk busana Muslim kepada masyarakat.

(3). Identity

Identity ialah bagaimana pelaku personal branding melakukan representasi diri dalam jaringan yang meliputi koneksi yang dibuat dan isi pesan yang dipublikasikan ke dalam jaringan ini. Identity ini dapat dilihat dari identitas produkproduk yang dijual oleh Zaskia yang simple namun tetap elegan dan casual sehingga mampu menarik masyarakat untuk tertarik membeli produk tersebut.

Selain ketiga elemen di atas, ada elemen-elemen lain yang merupakan hasil persinggungan antara ketiga elemen utama yang turut memengaruhi pembentukkan online personal brand, yakni sebagai berikut.

(1). Getting Found

Getting found merupakan perpotongan dari Identity dan Skill Set. Artinya, elemen ini terpenuhi apabila publik dapat menemukan Skill Set yang dimiliki pelaku personal branding dalam jaringan. Hal ini dapat dilihat dari pengelolaan bisnis online shop milik Zaskia Adya Mecca yang mampu diakses oleh masyarakat dan tertarik untuk membeli produk tersebut.

(2). Brand Experience

Brand experience merupakan kombinasi antara nilai rasional dan nilai emosional, yang merupakan keseluruhan pengalaman dan ingin diberikan ketika konsumen datang dan berhubungan dengan pelaku personal branding. Hal ini dapat dilihat dari perjalanan dan pengalaman Zaskia Adya Mecca ketika berhijab dan berniat untuk membuka bisnis busana Muslim ini baik secara online maupun offline, sehingga mampu menginspirasi 
para wanita muslimah untuk menutup aurat dan menggunakan hijab.

\section{(3). First Impression}

Elemen ini merupakan hasil dari perpotongan elemen Aura dan Identity yang artinya meliputi impresi pertama dari target audiens ketika mengunjungi saluran branding tanpa menganalisa Skill Set yang dimiliki. Hal ini dapat dilihat dari penilaian masyarakat terhadap Zaskia Adya Mecca yang dikenal sebagai artis Muslimah dalam menggunakan busana muslim \& karakter produk yang dijual oleh Zaskia yang dinilai simple namun tetap elegant dan casual oleh masyarakat.

Online shop adalah suatu proses pembelian barang atau jasa dari mereka yang menjual barang atau jasa melalui internet di mana antara penjual dan pembeli tidak pernah bertemu atau melakukan kontak secara fisik yang di mana barang yang diperjualbelikan ditawarkan melalui display dengan gambar yang ada di suatu website atau toko maya. Setelahnya pembeli dapat memilih barang yang diinginkan untuk kemudian melakukan pembayaran kepada penjual melalui rekening bank yang bersangkutan. Setelah proses pembayaran di terima, kewajiban penjual adalah mengirim barang pesanan pembeli ke alamat tujuan.

\section{METODE}

Adapun metodologi penelitian yang digunakan dalam penelitian ini adalah metodologi penelitian kualitatif dengan pendekatan studi kasus. Penelitian studi kasus menurut Cresswell (2015) adalah pendekatan kualitatif yang penelitinya mengeksplorasi kehidupan nyata, sistem terbatas (berbagai kasus) melalui pengumpulan data yang detail dan mendalam yang melibatkan beragam sumber informasi atau sumber informasi majemuk (misalnya pengamatan, wawancara, bahan audiovisual, dan dokumen dan berbagai laporan) dan melaporkan deskripsi kasus dan tema kasus. Menurut Cozby (2009) yang dikutip oleh Ardianto (2016) bahwa studi kasus memberikan deskripsi tentang individu. Individu ini biasanya adalah orang, tapi biasa juga sebuah tempat seperti perusahaan, sekolah, dan lingkungan sekitar.

Tipe studi kasus yang digunakan dalam penelitian ini adalah tipe studi kasus instrumental tunggal. Menurut Stake (1995) yang dikutip oleh Cresswell (2015), studi kasus instrumental tunggal ini peneliti memfokuskan pada isu atau persoalan, kemudian memilih satu kasus terbatas untuk mengilustrasikan persoalan.

Penelitian berfokus pada satu isu, yaitu personal branding dan menjadikan kasus mengenai kegiatan personal brandingdan online shop Muslim fashion yang dilakukan oleh Zaskia Adya Mecca sebagai selebritis dalam memromosikan barang berupa baju-baju muslim di media sosial instagram dan website untuk mengilustrasikan isu tersebut. Dengan itu, peneliti berharap untuk mendapatkangambaran dan pemahaman yang luas mengenai isu tersebut dengan mengelaborasi kasus ini dalam sebuah studi kasus yang memiliki tipe studi kasus instrumental tunggal.

Instrumen penelitian yang digunakan dalam penelitian ini adalah menggunakan wawancara secara mendalam, observasi, studi pustaka, dan penelusuran secara online. Adapun dalam wawancara secara mendalam ini, informan yang dipilih adalah pemilik usaha dari meccanism.co, pengamat moeslim fashion, ahli media online, dan costumer yang merasakan langsung tentang produkproduk yang telah dikeluarkan,selain itu juga peneliti melakukan observasi 
dengan cara observasi nonpartisipan, studi pustaka dengan cara memperoleh telaah teori-teori komunikasi dan teoriteori pendukung yang dapat memberikan penjelasan mengenai pokok-pokok permasalahan yang diteliti. Dalam studi pustaka, peneliti menggunakan berbagai buku dan jurnal tentang personal branding dan online shop. Dan yang terakhir adalah penelusuran secara online dengan cara penelusuran ke akun instagram Zaskia Adya Mecca serta website online shop miliknya sebagai data pendukung penelitian.

Teknik analisis data yang digunakan di dalam penelitian ini adalah dengan menggunakan teknik analisis data interaktif Miles and Hubersman yang dikutip oleh Sugiyono (2011) bahwa analisis data kualitatif dilakukan secara interaktif dan berlangsung secara terusmenerus sampai tuntas, sampai datanya jenuh yang dilakukan berdasarkan kepada 3 aktivitas yang dilakukan yaitu dengan cara reduksi data, penyajian data, penarikan data serta pengujian kesimpulan yang valid dan dapat dipertanggungjawabkan.

\section{HASIL PENELITIAN DAN PEMBAHASAN}

Di era persaingan bisnis yang semakin banyak dan semakin meningkat, kalangan artis menjadi magnet utama dalam segala bidang, adapun alasan artis menjadi trend dalam dunia bisnis saat ini adalah karena artis ini tidak selamanya bisa menunjukkan popularitasnya selama bertahun-tahun, terkadang popularitasnya naik terkadang turun, selain itu kebanyakan dari artis ini terjun ke dunia bisnis adalah karena berawal dari hobi, yaitu hobi memasak dan hobi desain fashion sehingga hobi tersebut dikembangkan ke dalam bentuk bisnis.

Fenomena artis terjun ke dunia bisnis ini tidak hanya dilakukan oleh artis Indonesia saja tetapi artis di luar negeri pun terjun ke dunia bisnis di mana dilakukan dengan cara memanfaatkan ketenaran atau popularitas dari sang artis tersebut.

Studi terdahulu yang membahas fenomena artis yang terjun ke dunia bisnis ini dilakukan Marta Martina dan Silvia Vacirca di dalam Jurnalnya yang berjudul "The Celebrity Factory : New Modes Of Fashion Entrepreuneurship" di mana dalam jurnal tersebut dijelaskan tentang kesuksesan dari Kim Kadarshian yang mampu membuat masyarakat dunia terkejut.

Kim Kadarshian ini melakukan bisnis fashion yang dikenal dengan butik D.A.S.H dan bisnis make up yang dinamai Kylie Cosmetic yang dimana penjualannya meningkat secara drastis berkat kepopuleran dari Kim Kadarshian. Kim Kadarshian ini dikenal sebagai sosok yang glamour dan pintar untuk memanfaatkan peluang yang ada salah satunya adalah untuk berwirausaha sebagai modal untuk memanfaatkan popularitasnya.

Berdasarkan hasil observasi, wawancara dan pengumpulan data ada 4 hal penting yang diperoleh dalam kegiatan personal branding selebritis Zaskia Adya Mecca dan penggunaan online shop sebagai media untuk memasarkan produk-produk busana Muslim milik Zaskia Adya Mecca.

Pertama adalah motif melakukan personal branding dengan cara melakukan terobosan dalam bisnisnya, yaitu dengan cara menggunakan media online, yaitu instagram dan website online.

Mengapa Zaskia memilih instagram dan website sebagai media untuk memasarkan produk-produk yang dia miliki dan apa keuntungan menggunakan instagram dan website sebagai media untuk memasarkan produk-produknya?.

Berawal pada Tahun 2012, Kakaknya Zaskia Adya Mecca, yaitu Tasya Nur Medina, iseng-iseng untuk 
membuat baju untuk dipakai secara pribadi. Eh, ternyata teman serta kerabat banyak yang suka dan memaksa untuk minta dibikinkan baju tersebut dan akhirnya dari mulut ke mulut menyebarlah dan muncul idelah untuk membuka bisnis tersebut sampai-sampai Zaskia tidak bisa melakukannya sendiri dan sekarang dibantu juga oleh adik saya yaitu Haykal Kamil. Adapun bisnis ini sudah memiliki berbagai cabang yaitu di Jakarta, Bandung, Yogyakarta dan Makassar.

Di era yang serba canggih apalagi dengan penggunaan media sosial seperti instagram \&website untuk memasarkan suatu produk, hal ini menjadi penting untuk digunakan khususnya untuk mengetahui tentang personal branding bagi kalangan selebriti. Menurut Mc Nally \& Speak (2012), ada beberapa karakteristik yang harus diperhatikan dalam merancang personal brand yang kuat yakni sebagai berikut :

(a). Khas, dari segi khas produk-produk Zaskia Adya Mecca ini memiliki ciri khas, di antaranya adalah ciri khas baju Zaskia Adya Mecca itu memberi kesan ciri khas mudah diingat. Pada koleksi terbarunya Zaskia ingin menampilkan karakter Muslim yang lebih minimalis karena menurutnya baju Muslim yang ada sekarang kebanyakan terlalu berlebihan sebenarnya hijab itu akan membuat supaya tidak menarik perhatian tapi kadangkadang ketika kita memakai hijab yang heboh,itu akan jadi menarik perhatian juga itu hal utama yang menjadi menarik perhatian konsumen (pembeli). Kebanyakan konsumen membeli produk dari Zaskia sebagai trend busana Muslim masa kini serta brand dari Zaskia Adya Mecca selaku owner juga sangat memengaruhi banyaknya pembeli. Dari segi harga/budget yang ditawarkan bias dikategorikan konsumen (pembeli) dari menengah keatas karena harga yang ditawar termasuk harga yang tinggi tetapi sesuai dengan kualitas barang yang djual.

(b). Relevan, dari segi relevan bahwa produk-produk yang dimiliki Zaskia Adya Mecca ini adalah model-model yang dijual Saskia sangat cocok dipakai diberbagai kalangan dengan warna warna yang lembut serta model baju yang sederhana tetapi elegan sangat cocok dipakai oleh konsumen. Adapun relevansinya adalah sudah memenuhi kebutuhan wanita Muslimah karena barang yang dijual sudah lengkap sekarang, mulai baju-baju sampai dengan jilbabnya.

(c). Konsisten, dari segi konsisten bahwa produk-produk yang dimiliki pada umumnya sudah konsisten mengeluarkan bajunya dan seharusnya ada jadwal harus direncanakan dalam mengeluarkan produknya agar masyarakat tidak bosan akan produk tersebut. Sarannya agar produk tersebut konsisten yaitu dengan cara menurunkan harga-harga produknya sehingga tidak hanya kalangan menengah ke atas yang bisa membelinya, tetapi semua kalangan bisa membelinya.

Menurut Ryann Frischmann (2014), online personal branding ini merupakan suatu upaya merepresentasikan diri dan sebagai sarana untuk interaksi antara seseorang dengan orang lain yang berada di dunia maya. Adapun ada 3 elemen utama dalam online personal branding, yaitu skill set, aura dan identity.

Pada elemen skill set yang menampilkan sisi nilai fungsional dan rasional, Zaskia Adya Mecca menuangkan pesan-pesan yang menarik 
dalam memasarkan produknya melalui instagram pribadinya, instagram online shop miliknya dan website. Hal ini dilakukan untuk menarik konsumen membeli produk-produknya baik secara online maupun offline. Ketika memposting produk-produk yang dimiliki Zaskia Adya Mecca, yaitu baju-baju atau kerudung tidak begitu sering dilakukan secara setiap hari, kalaupun ada produkproduk atau model-model terbaru, kita akan share atau posting di akun official instagram dari meccanism.co dan website dan biasanya dalam 1 bulan owner hanya bisa mendesain 2 baju dan dalam 1 bulan paling sering 2 kali memposting produk baik kerudung atau baju."

Elemen aura ini merepresentasikan nilai emosional yang mempengaruhi persepsi khalayak. Aura ini meliputi kepribadian, penampilan, gaya dan kharisma yang ditonjolkan oleh Zaskia Adya Mecca di instagram dan website.

Berdasarkan penelusuran online di account instagram pribadi dan instagram online shop milik Zaskia Adya Mecca ini bahwa beliau ini memiliki sifat yang baik, religious, selalu tersenyum, ramah, dan selalu memberikan energi-energi positif bagi orang-orang yang ada di sekitarnya, sehingga aura ini menimbulkan dampak positif bagi masyarakat dan khususnya bagi kemajuan online shop milik Zaskia Adya Mecca ini diantaranya penghasilan dari bisnis online dan offline itu lumayan besar kalau di rata-ratakan, penghasilan online lebih besar yaitu sebesar 65\% dibandingkan offline sebesar 35\%.

Elemen yang terakhir yaitu identity yang di mana menurut Frischmann ini melihat bagaimana Zaskia Adya Mecca melakukan representasi diri di dalam media sosial, khususnya media sosial instagram dan melalui instagram dan website ini, Zaskia Adya Mecca merepresentasikan dirinya sebagai selebritas sekaligus entrepreneur yang sukses memikat para penggemar dan para konsumennya untuk membeli produkproduk yang dimiliki oleh Zaskia Adya Mecca. Adapun para penggemar dan konsumennya cenderung untuk membeli produk-produk milik Zaskia Adya Mecca secara online dengan alasan cenderung lebih praktis dan lebih mudah.

Adapun getting found dari Zaskia Adya Mecca ini adalah pengelolaan akun website online shop dan instagram yang setiap harinya selalu update tentang produk-produk yang dikeluarkan sehingga masyarakat tertarik untuk membeli produk tersebut. Dari segi brand experience mengenai toko yang dijual Zaskia Adya Mecca ketika mengunjungi tokonya nyaman, bersih, dan rapi serta fasilitasnya lengkap seperti tempat mencoba dan kaca lengkap dan produk yang dijual ini dapat digunakan untuk wanita Muslimah dari berbagai kalangan, di antaranya kalangan anak-anak, remaja hingga orang dewasa. Sedangkan first impression dari Zaskia Adya Mecca ini adalah zaskia ini memiliki karakter yang sederhana, pintar, ramah terhadap orang, manis, dan sangat kagum karena wanita yang super sibuk sebagai artis sekaligus istri tetapi masih bisa membuka usaha fashion. Dia ini selalu menggunakan pakaian-pakaiannya yang simple sehingga membuat orang-orang tertarik untuk membeli produknya dan selalu berpikir kreatif dalam menciptakan inovasiinovasi baru dalam dunia bisnisnya.

Personal Branding dari Zaskia Adya Mecca ini dalam memasarkan produk-produk bisnis online shop ini adalah bahwa produk-produk yang dijual oleh Zaskia Adya Mecca ini dinilai sudah sesuai dengan kebutuhan wanita muslimah pada umumnya dan mempunyai ciri khas tersendiri dalam setiap produknya.

Sedangkan kepribadian dari Zaskia Adya Mecca dalam membentuk personal branding ini adalah bahwa Zaskia Adya Mecca ini memiliki karakter yang pintar, dan mampu untuk terus melakukan 
inovasi-inovasi terbaru dalam bisnisnya, dan yang penting adalah semua bisnisbisnis yang dijalankan oleh Zaskia ini diharapkan mampu memberikan manfaat bagi orang lain.

\section{SIMPULAN}

Personal branding selebritas yang dilakukan Zaskia Adya Mecca ini dinilai berhasil memikat para penggemar dan para konsumennya untuk membeli produk-produk yang dimiliki oleh Zaskia Adya Mecca ini baik melalui akun official instagram online shop milik Zaskia ataupun melalui website. Motif dari Zaskia Adya Mecca ini melakukan personal branding melalui media sosial di instagram dan website adalah sebagai sarana untuk mempromosikan produkproduk yang dimiliki oleh Zaskia Adya Mecca kepada para penggemar dan konsumennya untuk tertarik membeli produk-produk yang dijualnya baik secara online maupun offline. Adapun keunggulan produk-produk yang dimiliki oleh Zaskia Adya Mecca adalah modelmodelnya lebih menarik, elegan, dan tidak pasaran dan dari segi harganya masih terjangkau oleh beberapa kalangan.

Dalam memasarkan produk-produk yang dimiliki oleh Zaskia melalui online shop baik account instagram maupun website. Namun, ada beberapa kendala yang terjadi, di antaranya terkadang konsumen suka ragu-ragu untuk membeli barang sehingga susah menandai barang dan janji akan melakukan transfer ketika pas hari $\mathrm{H}$ pembelian konsumen menghilang.

\section{DAFTAR PUSTAKA}

Amanda, Vivi Imawati, Ayu Wahyuni Solihah dan Mohammad Shihab. (2016). Analisis Personal Branding Fashion Blogger Diana Rikasari. Jurnal Ilmu Sosial dan Ilmu Politik, Volume 5 Nomor 3

Ardianto, E. (2016). Metodologi Penelitian untuk Public Relations Kuantitatif dan Kualitatif. Bandung: Simbiosa Rekatama Media.

Cresswell, J. W. (2015). Penelitian Kualitatif dan Desain Riset Edisi 3. Yogyakarta: Pustaka Pelajar.

Frischmann, R. (2014). Online Personal Brand: Skill Set, Aura, and Identity. USA: Create Space Independent Publishing Platform.

Fuady, M. E. (2002). Surat Kabar Digital sebagai Media Konvergensi di Era Digital. Mediator: Jurnal Komunikasi, 2 (1), halaman 55-61.

Marta, Martina dan Silvia Vacira. (2017). The Celebrity Factory: New Modes of Fashion Entrepreneurship. Zone Moda Journal. Vol. 7.

Mc Nally, D., \& Speak, K. D. (2012). Be Your Own Brand: Achieve More of What You Want by Being More of Who You Are. San Francisco: Berrett-Koehler Publishers.

Sugiyono. (2011). Metode Penelitian Kualitatif, Kuantitatif dan $R \& D$. Bandung : CV Alfabeta.

Wasesa, S.A. (2013). Political Branding \& Public Relations. Jakarta: Gramedia Pustaka Utama. 